\title{
Relative Contribution of Seed Tuber- and Soilborne Inoculum to Potato Disease Development and Changes in the Population Genetic Structure of Rhizoctonia solani AG 3-PT under Field Conditions in South Africa
}

\author{
Norman Muzhinji, Department of Plant and Soil Sciences, University of Pretoria, Hatfield, Pretoria 0001, South Africa; and Tobacco Research \\ Board, Harare, Zimbabwe; James W. Woodhall, Parma Research and Extension Center, University of Idaho, Parma 83660; Mariette Truter, \\ Agricultural Research Council-Vegetable and Ornamental Plants, Pretoria 0001, South Africa; and Jacquie E. van der Waals, ${ }^{\dagger}$ Department of \\ Plant and Soil Sciences, University of Pretoria, Hatfield
}

\begin{abstract}
Understanding the contribution of seed tuber- and soilborne inocula of Rhizoctonia solani AG 3-PT in causing potato disease epidemics is an important step in implementing effective management strategies for the pathogen. A 2-year study was conducted to evaluate the contribution of each source of inoculum using an integrative experimental approach combining field trials and molecular techniques. Two distinct sets of genetically marked isolates were used as seed tuberborne and soilborne inocula in a mark-release-recapture experiment. Disease assessments were done during tuber initiation and at tuber harvest. Both inoculum sources were found to be equally important in causing black scurf disease, whereas soilborne inocula appeared to be more important for root and stolon infection, and seedborne inocula contributed more to stem canker. However, seed tuber-transmitted genotypes accounted for $60 \%$ of the total recovered

isolates when genotyped using three polymerase chain reaction restriction fragment length polymorphism markers. The changes in population structure of the experimental $R$. solani population over the course of the growing season and across two growing seasons were investigated using eight microsatellite markers. The populations at different sampling times were somewhat genetically differentiated, as indicated by Nei's gene diversity $(0.24$ to 0.27$)$ and the fixation index $\left(F_{\mathrm{ST}}\right)$. The proportion of isolates with genotypes that differed from the inoculants ranged from 13 to $16 \%$ in 2013 and 2014, respectively, suggesting the possibility of emergence of new genotypes in the field. Because both soilborne and tuberborne inocula are critical, it is important to ensure the use of pathogen-free seed tubers to eliminate seed tuberborne inoculum and the introduction of new genotypes of $R$. solani for sustainable potato production in South Africa.
\end{abstract}

Rhizoctonia solani Kühn is a major pathogen of potato that negatively impacts the qualitative and quantitative yield, with estimated annual yield losses of approximately $30 \%$ (Banville 1989). R. solani species complex exists in many different groups and presently, 13 anastomosis groups (AG) are recognized, with many subgroups (Carling et al. 2002). The predominance and aggressiveness of $R$. solani AG 3 potato-infecting subgroup (AG 3-PT) on potato has been confirmed in South Africa (Muzhinji et al. 2015) and elsewhere (Das et al. 2014; Fiers et al. 2011; Woodhall et al. 2007).

Infection of potato by $R$. solani AG 3-PT originates from inoculum present as sclerotia or hyphae on seed tubers or already inhabiting the soil where the potato crop is grown (Balali et al. 2007; Sneh et al.1996). Several strategies are used to control Rhizoctonia diseases on potato, including the use of biocontrol agents, treating seed tubers or field soils with fungicides, and crop rotation (Tsror 2010). However, avoidance of planting in Rhizoctonia sp.-infested fields and planting pathogenfree certified potato seed are often the most practical disease control measures for the potato grower.

The role of seed tuber- and soilborne inocula in the development of Rhizoctonia diseases on potato has been extensively studied but the relative importance of each source of inoculum has not been definitively established (Atkinson et al. 2010; Brierley et al. 2016; Frank and Leach 1980; Tsror (Lahkim) and Peretz-Alon 2005; van Emden 1965). James and McKenzie (1972) demonstrated that soilborne inoculum is more important than seed tuberborne inoculum, while Atkinson et al. (2010) and, more recently, Brierley et al. (2016) concluded that seed tuberborne inoculum is more strongly associated with potato diseases than soilborne inoculum. In contrast, other studies have shown that seed tuber- and soilborne inocula are both important in

${ }^{\dagger}$ Corresponding author: J. E. van der Waals;

E-mail: Jacquie.vanderwaals@up.ac.za

Accepted for publication 30 July 2017.

(C) 2018 The American Phytopathological Society potato disease development, with each source of inoculum playing a different role at different stages of plant growth and development (Atkinson et al. 2010; Brierley et al. 2016; Frank and Leach 1980; Tsror (Lahkim) and Peretz-Alon 2005). However, these observations and that of the importance of seed tuberborne inoculum as the primary inoculum in Rhizoctonia disease epidemics on potato still lacks conclusive evidence.

The increase in the array of molecular techniques and computing technologies offers endless possibilities of conducting mark-releaserecapture experiments that allow tracking of inoculum sources during disease development and, thus, determine the inoculum origin (Bardin et al. 2014; Sommerhalder et al. 2010; Zhan and McDonald 2013; Zhan et al. 1998). Mark-release-recapture experiments have been reported for the wheat pathogen Phaeosphaeria nodorum (Bennett et al. 2007; Shah et al. 1995) and other pathogens (Zhan and McDonald 2013). The development and validation of selectively neutral, codominant, and highly polymorphic molecular markers for $R$. solani AG 3-PT (Ceresini et al. 2002) offers practical feasibility of tagging and tracking $R$. solani AG 3-PT genotypes across generations in a markrelease-recapture experiment.

Another possible source of $R$. solani AG 3-PT inoculum is basidiospores that have frequently been observed during canopy closure as a white-collar on the base of potato stems (Ferrucho et al. 2013; Ogoshi 1987). Their role as an inoculum source in Rhizoctonia disease epidemics on potato has not been demonstrated (Jeger et al. 1996). In other crops such as tobacco and tomato, basidiospores have been reported to serve as primary or secondary inoculum in addition to seed tuberborne and soilborne inocula (Bartz et al. 2010; Shew and Melton 1995). Several studies have provided compelling evidence that basidiospores play an important role in shaping the population genetic structure of $R$. solani AG 3-PT on potato (Ceresini et al. 2002; Ferrucho et al. 2013). Changes in population genetic structure allow pathogens to evolve and adapt more rapidly to changing environments, reducing the useful life span of fungicides and resistant cultivars, thus making disease control more difficult (McDonald and Linde 2002).

The production of basidiospores in the field, theoretically, makes Rhizoctonia diseases on potato polycyclic, with several generations 
of Rhizoctonia spp. reproduction across growing seasons. A better understanding of how the field population evolves during the course of the growing season or across seasons can be useful for implementing more sustainable disease management strategies (McDonald and Linde 2002).

The aim of this work was twofold. The first objective was to investigate the role of seed tuber- and soilborne inocula on Rhizoctonia disease development on potato using an integrative experimental approach combining both conventional plant pathology procedures and molecular methods. In South Africa, there is little knowledge concerning the effects, importance, and relative contribution of different $R$. solani inoculum sources on the epidemiology and severity of $R h i-$ zoctonia potato diseases. The second objective was to determine whether the genetic structure within a field changes over the course of the growing season.

\section{Materials and Methods}

Experiment 1: Contribution of seed tuber- and soilborne inoculum sources to $R$. solani AG 3-PT disease development on potato. Field trials were conducted at the University of Pretoria experimental plots. The field experiments were conducted over two growing seasons: September to December 2013 during year 1 and March to June 2014 during year 2.

Experimental design. The pathogen-free certified 'Harmony' seed tubers were planted in year 1 (2013) and year 2 (2014). Prior to planting the plots, soil was sampled along diagonal transects to check for $R$. solani infestation. A baiting method with autoclaved oat seed was used to isolate Rhizoctonia spp. from field soils (Sneh et al. 1966). The plots had no history of $R$. solani infestation and were disinfested by fumigation with formalin at $0.91 \mathrm{~kg}$ per $9.3 \mathrm{~m}^{3}, 4$ weeks prior to planting, to minimize the presence of soilborne pathogens before the start of the trial. The fumigated soil was rotovated every week until planting. Experimental plots consisted of four rows, $4.5 \mathrm{~m} \mathrm{long}$, $1.5 \mathrm{~m}$ wide, and $70 \mathrm{~cm}$ apart, with seed pieces planted $25 \mathrm{~cm}$ apart within a row. Four treatments were used: uninfested soil with uninoculated seed tubers (control treatment), infested soil with uninoculated seed tubers, uninfested soil with inoculated seed tubers, and infested soil with inoculated seed tubers. Each plot represented one treatment and the experimental layout was a randomized complete block design with four replicates. Adjacent plots were separated by two buffer rows of potato plants. The management of the field trial followed the local practice for commercial potato production.

Inoculum preparation. Two groups of $R$. solani AG 3-PT isolates with two distinct multilocus genotypes (MLG), as assayed with three polymerase chain reaction (PCR) restriction fragment length polymorphisms (RFLP) (Table 1) developed by Ceresini et al. (2002), were used as seed tuberborne and soilborne inoculum. Each group of MLG was made up of five isolates. Soil inoculum was composed of isolates Rh24, Rh25, Rh28, Rh106, and Rh114 while seed tuberborne inoculum was made up of Rh19, Rh29, Rh50, Rh100, and Rh101. The AG identity of the isolates was confirmed by DNA sequencing of the internal transcribed spacer (ITS) region, as described in a separate study (Muzhinji et al. 2015). Soilborne inoculum was prepared according to the method of Atkinson et al. (2010), with slight modifications. In brief, $R$. solani isolates were grown on potato dextrose agar (PDA; Biolabs) plates ( $90 \mathrm{~mm}$ in diameter) for 7 days at $25^{\circ} \mathrm{C}$. For each isolate, 30 plates covered with mycelia were homogenized by blending with 4 liters of sterile water into slurry, mixed with 10 liters of vermiculite, and incubated for 5 weeks with shaking after every 2 days. Soil was inoculated 2 days prior to planting by spreading the Rhizoctonia sp.-colonized vermiculite throughout the potato field at an approximate rate of 2 liters per $9 \mathrm{~m}$ of row. Seed tuberborne inoculum was prepared according to a modified method of Simons and Gilligan (1997). In brief, $R$. solani isolates were grown on PDA plates for 14 days at $25^{\circ} \mathrm{C}$. Seed tubers were coated with a sludge prepared by mixing 20 colonized agar blocks ( 5 by $5 \mathrm{~mm}$ ) with $250 \mathrm{ml}$ of distilled water and $500 \mathrm{~g}$ of autoclaved soil for 20 seed tubers. The coated seed tubers were incubated for 2 days at $25^{\circ} \mathrm{C}$ to allow fungal colonization.

Disease assessments. Potato plants were sampled twice during the course of the growing season for disease assessments. Emergence and stem counts were taken 21 days after planting. Emergence counts were conducted to determine the incidence of misses caused by seed piece decay. The numbers of stems per tuber piece were counted on every second plant in the center two rows of each plot to determine whether $R$. solani infection decreased the number of stems per plant. At 60 days, whole plant samples, 10 plants per plot, were excavated from the two center rows, rinsed with tap water to remove soil, and examined for stem canker, stolon and root infection, and hymenia on the canopy. Isolations were made from cankers on the roots, stems, and stolons to verify the presence of $R$. solani. An additional 10 plants from the center two rows of each plot were harvested 130 days after planting; 50 tubers per plot were randomly selected, washed, and visually rated to estimate the percentage of tuber surface covered with back scurf.

Disease severity rating was done according to Woodhall et al. (2008) using a 0 -to-4 scale, where $0=$ no damage or lesions present; $1=$ one to several lesions less than $5 \mathrm{~mm}$ in size; $2=$ lesions larger than $5 \mathrm{~mm}$ and some girdling present; $3=$ larger lesions and girdling; and $4=$ all roots, stems, and stolons killed. Black scurf symptoms on progeny tubers were rated using the following scale: $0=$ no sclerotia present and $1=$ less than $1,2=1$ to $10,3=11$ to $20,4=21$ to 50 , and $5=\geq 51 \%$ tuber surface area covered in sclerotia. Rhizoctonia diseases on stems and stolons were presented as a disease index (DI). DI for stems and black scurf were calculated as described previously (Muzhinji et al. 2015).

Table 1. Polymerase chain reaction restriction fragment length polymorphism (RFLP) markers used in this study (Ceresini et al. 2002)

\begin{tabular}{|c|c|c|c|c|c|c|}
\hline RFLP locus & Primer sequence $\left(5^{\prime}-3^{\prime}\right)$ & Annealing temperature $\left({ }^{\circ} \mathrm{C}\right)$ & Fragment size (bp) & Restriction enzyme & Alleles & Size (bp) \\
\hline \multirow[t]{2}{*}{ pP09 } & F-TGTCAGTCGAGTTATCCGCGA & 55 & 530 & HhaI & 1 & 250 \\
\hline & R-GATCAAGTGTATGCGCATGCG & $\ldots$ & $\ldots$ & $\ldots$ & 2 & 320 \\
\hline \multirow[t]{3}{*}{ pP42 } & F-GTTTTTGTAGTGCACGGGGT & 56 & 1,970 & HindIII & 1 & 1,250 \\
\hline & R-ATTCAACGTCTGTCGGTACGG & $\ldots$ & $\ldots$ & $\ldots$ & 2 & 1,020 \\
\hline & & $\ldots$ & $\ldots$ & $\ldots$ & 3 & 1,970 \\
\hline \multirow[t]{2}{*}{ pP45 } & F-TTGTTCATCGTCCTCGAGTCTC & 56 & 965 & HindIII & 1 & 765 \\
\hline & R-ATCGGGTAAATTGCTACGCGA & $\ldots$ & $\ldots$ & $\ldots$ & $\ldots$ & $\ldots$ \\
\hline
\end{tabular}

Table 2. Multilocus genotypes representing soilborne (Soil) and seed tuberborne (Tuber) inocula used ${ }^{\mathrm{z}}$

\begin{tabular}{|c|c|c|c|c|c|c|c|c|c|c|c|c|c|c|c|c|}
\hline \multirow{3}{*}{$\begin{array}{l}\text { Inocula } \\
\text { Soil }\end{array}$} & \multicolumn{16}{|c|}{$\mathbf{T C}_{-}$} \\
\hline & \multicolumn{2}{|c|}{ AG3_0 } & \multicolumn{2}{|c|}{ AG3_1 } & \multicolumn{2}{|c|}{ AG3_6 } & \multicolumn{2}{|c|}{ AG3_7 } & \multicolumn{2}{|c|}{ AG3_10 } & \multicolumn{2}{|c|}{ AG3_16 } & \multicolumn{2}{|c|}{ AG3_18 } & \multicolumn{2}{|c|}{ AG_19 } \\
\hline & 151 & 151 & 152 & 165 & 197 & 203 & 244 & 244 & 245 & 248 & 327 & 330 & 346 & 346 & 320 & 356 \\
\hline Tuber & 151 & 151 & 152 & 152 & 197 & 203 & 244 & 244 & 245 & 245 & 323 & 346 & 321 & 324 & 343 & 346 \\
\hline
\end{tabular}

${ }^{\mathrm{z}}$ Alleles (designated by length in base pairs) present at each of the eight microsatellite are shown. 
Experiment 2: Genotypic shift in the $R$. solani AG 3-PT population under field conditions. Inoculated plots that contained both the seed tuber- and soilborne inoculum in 2013 were used in 2014 for the $R$. solani AG 3-PT population genetic changes experiment without reinoculation. Pathogen-free certified 'Up-to-date' seed tubers were planted in plots infested with both soil- and tuberborne inoculum. As in year 1 (2013), two sets of fungal isolations were made at tuber initiation stage (midseason) and at harvest stage (end of season).

Fungal isolation and DNA extraction. R. solani isolates were isolated from stem and stolon cankers, hymenia, roots, and black scurf

Table 3. Effects of seed tuber- or soilborne inocula of Rhizoctonia solani on the number of stems and percentage emergence (arcsine transformed) ${ }^{\mathrm{z}}$

\begin{tabular}{lllllc}
\hline & \multicolumn{2}{l}{ Number of stems } & & \multicolumn{2}{c}{ Emergence (\%) } \\
\cline { 2 - 3 } \cline { 5 - 6 } Inoculum source & $\mathbf{2 0 1 3}$ & $\mathbf{2 0 1 4}$ & & $\mathbf{2 0 1 3}$ & $\mathbf{2 0 1 4}$ \\
\hline Control & $2.8 \mathrm{a}$ & $3.2 \mathrm{a}$ & $77.3 \mathrm{a}$ & $90.0 \mathrm{a}$ \\
Soil & $2.2 \mathrm{~b}$ & $2.7 \mathrm{~b}$ & $59.9 \mathrm{~b}$ & $55.2 \mathrm{~b}$ \\
Soil and tuber & $1.8 \mathrm{c}$ & $2.5 \mathrm{c}$ & $56.9 \mathrm{~b}$ & $52.2 \mathrm{~b}$ \\
Tuber & $2.0 \mathrm{c}$ & $2.5 \mathrm{c}$ & $57.4 \mathrm{~b}$ & $55.2 \mathrm{~b}$ \\
\hline
\end{tabular}

${ }^{\mathrm{z}}$ Data were analyzed using the Fisher's protected $F$ test least significant difference $(P=0.05)$. Values in columns followed by the same letter are not significantly different according to Duncan's multiple range test $(P=0.05)$.

Table 4. Effect of seed tuber- or soilborne inocula of Rhizoctonia solani on root, stolon, stem, and black scurf disease index (DI) ${ }^{\mathrm{w}}$

\begin{tabular}{|c|c|c|c|c|c|c|c|c|}
\hline \multirow{2}{*}{$\begin{array}{l}\text { Inoculum } \\
\text { source }\end{array}$} & \multicolumn{2}{|c|}{$\begin{array}{c}\text { Root } \\
\text { infection }\end{array}$} & \multicolumn{2}{|c|}{$\begin{array}{l}\text { Stolon } \\
\text { canker }^{x}\end{array}$} & \multicolumn{2}{|c|}{ Stem canker ${ }^{y}$} & \multicolumn{2}{|c|}{ Black scurf $^{\mathrm{z}}$} \\
\hline & 2013 & 2014 & 2013 & 2014 & 2013 & 2014 & 2013 & 2014 \\
\hline Control & $0.0 \mathrm{c}$ & $0.0 \mathrm{c}$ & $0.0 \mathrm{~d}$ & $0.0 \mathrm{~d}$ & $0.0 \mathrm{~d}$ & $0.0 \mathrm{~d}$ & $0.0 \mathrm{c}$ & $0.0 \mathrm{~d}$ \\
\hline Soil & $14.5 \mathrm{~b}$ & $10.5 \mathrm{~b}$ & $8.5 \mathrm{~b}$ & $15.0 \mathrm{a}$ & $22.5 \mathrm{c}$ & $14.5 \mathrm{c}$ & $13.4 \mathrm{~b}$ & $5.8 \mathrm{c}$ \\
\hline $\begin{array}{l}\text { Soil and } \\
\text { tuber }\end{array}$ & $17.5 \mathrm{a}$ & $12.5 \mathrm{a}$ & $10.2 \mathrm{a}$ & $12.0 \mathrm{~b}$ & $37.0 \mathrm{a}$ & $22.5 \mathrm{a}$ & $17.6 \mathrm{a}$ & $11.3 \mathrm{a}$ \\
\hline Tuber & $13.0 \mathrm{~b}$ & $6.0 \mathrm{c}$ & $5.0 \mathrm{c}$ & $8.0 \mathrm{c}$ & $29.0 \mathrm{~b}$ & $17.4 \mathrm{~b}$ & $12.6 \mathrm{~b}$ & $7.8 \mathrm{~b}$ \\
\hline
\end{tabular}

${ }^{w}$ Values in columns followed by the same letter are not significantly different according to Duncan's multiple range test $(P=0.05)$.

$\mathrm{x}$ DI for roots and stolons was calculated by the formula DI $=\Sigma\left[0\left(n_{0}\right)+0.2\right.$ $\left.\left(n_{1}\right)+0.4\left(n_{2}\right)+0.6\left(n_{3}\right)+0.8\left(n_{4}\right)+1\left(n_{5}\right)\right] \times 100 /\left(N_{\text {total }}\right)$, where $n_{\mathrm{x}}=$ number of roots or stolons in the $x$ rating class and $N=$ total number of roots or stolons.

y DI for stems was calculated by the formula DI $=\Sigma\left[0\left(n_{0}\right)+0.2\left(n_{1}\right)+0.4\left(n_{2}\right)+\right.$ $\left.0.6\left(n_{3}\right)+0.8\left(n_{4}\right)+1\left(n_{5}\right)\right] \times 100 /\left(N_{\text {total }}\right)$, where $n_{\mathrm{x}}=$ number of stems or stolons in the $x$ rating class and $N=$ total number of stems or stolons.

${ }^{\mathrm{z}}$ DI for black scurf was calculated by the formula DI $=\Sigma\left[0\left(n_{0}\right)+0.25\left(n_{1}\right)+\right.$ $\left.0.5\left(n_{2}\right)+0.75\left(n_{3}\right)+1\left(n_{4}\right)\right] \times 100 /\left(N_{\text {total }}\right)$, where $n_{\mathrm{x}}=$ number of tubers in the $x$ rating class and $N=$ total number of tubers in each category. on potato tubers. Isolates obtained from the same treatment but different replications were pooled at each time point and were considered a population. Plants were first washed with tap water and placed on $2 \%$ water agar amended with streptomycin sulfate (100 $\mu \mathrm{g} /$ /liter). Colonies identified as $R$. solani under the microscope (Ogoshi 1975) were transferred to PDA and incubated at $25^{\circ} \mathrm{C}$ for 5 days. DNA extraction was done using the ZR soil microbe DNA kit (Zymo Research Corporation), according to the manufacturer's protocol recommendations. The identification of isolated AG was done using ribosomal DNA ITS sequencing, as described previously (Muzhinji et al. 2015).

PCR-RFLP analysis. $R$. solani isolates recovered from symptomatic tissues were genotyped using PCR-RFLP markers (Ceresini et al. 2002) to determine the most prevalent genotype and infer the source of the inoculum. Amplification of genomic DNA was carried out as described by Ceresini et al. (2002), with minor modifications. PCR conditions for all loci consisted of initial denaturation at $95^{\circ} \mathrm{C}$ for $3 \mathrm{~min} ; 35$ cycles of denaturation for $30 \mathrm{~s}$ at $95^{\circ} \mathrm{C}$, annealing for $30 \mathrm{~s}$ at a specific temperature for each RFLP locus (Table 1), and elongation for $45 \mathrm{~s}$ at $72^{\circ} \mathrm{C}$; and a final extension cycle of $7 \mathrm{~min}$. In each set, $5 \mu \mathrm{l}$ of the PCR products were electrophoresed on Metaphor agarose gel (Lonza) and the specific band for each locus determined. A total of $10 \mu$ l of dissolved DNA of each isolate was digested with HindIII and HhaI, according to the manufacturer's instructions. Typical restriction enzyme reactions consisted of $10 \mu \mathrm{l}$ of PCR product, $7.5 \mathrm{U}$ of enzyme, $2 \mu \mathrm{l}$ of $10 \times$ reaction buffer, $0.2 \mu$ l of bovine serum albumin, and water to a total volume of $20 \mu \mathrm{l}$. Reactions were incubated for $2 \mathrm{~h}$ and stopped by incubation at $75^{\circ} \mathrm{C}$ for $5 \mathrm{~min}$. Restriction fragments were separated on a $2 \%$ agarose gel in Tris-acetate-EDTA buffer and stained with ethidium bromide.

Microsatellite analysis. Microsatellite (simple-sequence repeat) analyses of the recovered isolates were done to monitor the shift of the inoculated $R$. solani population over a 2-year period. This was done by tracking the changes in genotypes of soil and seed tuberborne inoculants (Table 2). The population genetic changes experiment, in a broader context, simulated what would occur in a commercial field when inoculum is introduced and the potato growers subsequently prevent reintroduction of the pathogen. The genotype of each isolate was determined using the eight microsatellite markers (Ferrucho et al. 2009) with fluorescently labeled primers using the same amplification protocols as described previously (Muzhinji et al. 2016). The PCR products were first cooled on ice for 2 min and then separated on an ABI 3730xI Genetic Analyzer (Applied Biosystems). Fragment sizes were estimated and alleles were assigned using the program GeneMapper (v. 4.1; Applied Biosystems).

Table 5. Analyses of polymerase chain reaction restriction fragment length polymorphism genotypes of isolates of Rhizoctonia solani AG 3-PT recovered from infected roots, stolons, stems, and progeny tubers

\begin{tabular}{|c|c|c|c|c|c|c|c|c|c|}
\hline \multirow[b]{3}{*}{ Inoculum source } & \multirow[b]{3}{*}{ Sampling period ${ }^{w}$} & \multicolumn{8}{|c|}{ Genotypes ${ }^{v}$} \\
\hline & & \multicolumn{4}{|c|}{2013} & \multicolumn{4}{|c|}{2014} \\
\hline & & $\overline{N^{x}}$ & Seed tuber-borne ${ }^{y}$ & Soilborne $^{y}$ & Nonreleased $^{\mathbf{z}}$ & $N^{\mathbf{x}}$ & Seed tuber-borne ${ }^{y}$ & Soilborney $^{y}$ & Nonreleased $^{\mathrm{z}}$ \\
\hline \multirow[t]{2}{*}{ Control } & Midseason & - & - & - & - & - & - & - & - \\
\hline & End of season & - & - & - & - & - & - & - & - \\
\hline \multirow[t]{2}{*}{ Soil } & Midseason & 7 & - & 7 & - & 8 & - & 8 & - \\
\hline & End of season & 13 & - & 13 & - & 1 & - & 11 & - \\
\hline \multirow[t]{2}{*}{ Soil and tuber } & Midseason & 23 & 19 & 4 & - & 13 & 8 & 4 & 1 \\
\hline & End of season & 24 & 18 & 4 & 2 & 12 & 7 & 3 & 2 \\
\hline \multirow[t]{2}{*}{ Tuber } & Midseason & 10 & 10 & - & - & 8 & 8 & - & - \\
\hline & End of season & 11 & 11 & - & - & 11 & 11 & - & - \\
\hline Total & $\ldots$ & 88 & 58 & 28 & 2 & 63 & 34 & 26 & 3 \\
\hline
\end{tabular}

v Dash (-) indicates no R. solani isolated.

${ }^{\mathrm{w}}$ Midseason = tuber initiation; end of season $=$ harvest period.

${ }^{x}$ Number of isolates recovered and genotyped.

y Number of isolates with genotypes identical to the seed tuber- or soilborne inoculum.

${ }^{\mathrm{z}}$ Genotypes different from the inoculated genotypes. 
Data analyses. All statistical analyses were carried out using GENSTAT (v. 14.0; VSN International Ltd.). Analysis of variance was used to test the differences between variables and means separated by Fisher's protected $F$ test least significant difference. Data in percentages were arcsine transformed before analysis. Recovered $R$. solani isolates were genotyped using PCR-RFLP to determine whether they originated from a seed tuber- or soilborne inoculum source. Isolated $R$. solani was considered to be seed tuber- or soilborne if it had a PCR-RFLP profile identical to the seed tuber- or soilborne genotypes used for inoculations.

Genetic variation and population differentiation. Isolates sampled at the same sampling time points were treated as a single population. Data on the number of alleles per locus and allelic frequencies per locus and per population were assessed using the program CONVERT, v. 1.31 (Glaubitz 2004). Genotypic diversity was computed using the program MULTILOCUS, v 1.3 (Agapow and Burt 2001). Allele frequencies were calculated using GeneAIEx, version 6.5 (Peakall and Smouse 2006). Each combination of alleles at the eight loci defined an MLG and was implemented in GENOTYPE (Meirmans and van Tienderen 2004). Nei's measures of genetic distance and population differentiation were used to estimate the level of population subdivision between years and were implemented in FSTAT 2.9.3.2 (Goudet 1995). Population differentiation over the sampling periods during the growing season and between years was measured by $F_{\mathrm{ST}}$ statistics implemented in program ARLEQUIN, v 3.5.2, using 1,100 randomizations (Excoffier and Lischer 2010). To evaluate the associations among loci in each sample, the index of association $\left(\mathrm{I}_{\mathrm{A}}\right)$ and an unbiased estimate of multilocus linkage disequilibrium ( $\mathrm{rBarD})$ were used. The rBarD is much less dependent on the number of loci. They were computed using Multilocus 1.3 software, and 1,000 artificially recombined data sets were used to determine the statistical values of the test (Agapow and Burt 2001). A value of zero indicates linkage equilibrium, which is expected in random mating populations. A value significantly different from zero indicates linkage between loci, and is high in clonal populations.

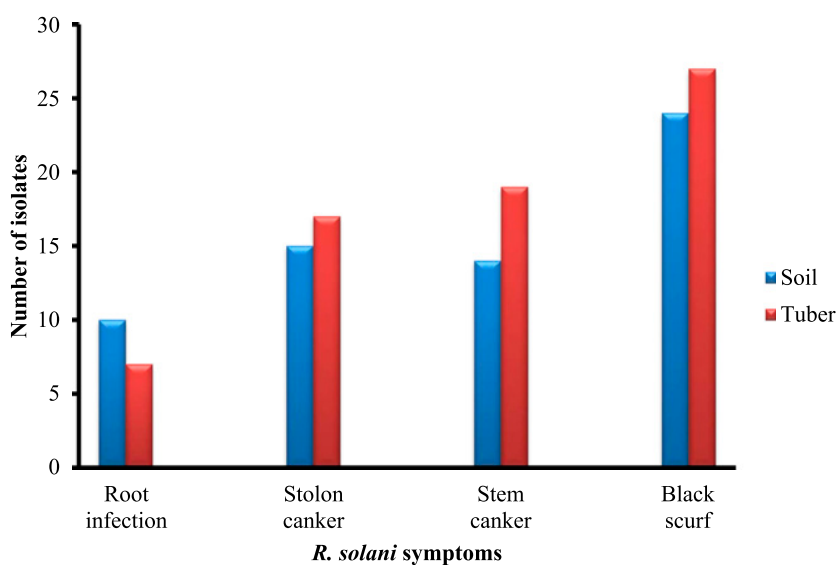

Fig. 1. Frequency distribution of seed tuberborne and soilborne polymerase chain reaction restriction fragment length polymorphism genotypes associated with Rhizoctonia solani diseases on potato sampled from the experimental plots over 2 years.

\section{Results}

$R$. solani AG 3-PT disease development. The common $R$. solani symptoms on potato (namely, stem canker and stolon and root infection) were the major symptoms observed in the midseason assessments from plots at the University of Pretoria. At the end of the season, black scurf was the most conspicuous symptom, although white-collar, malformed, or cracked tubers and elephant hide were observed on progeny tubers, albeit at low frequencies. $R$. solani symptoms on potato were not observed on control treatments.

Emergence and stem counts. Percent emergence was significantly higher $(P<0.05)$ in control plots than in treatment plots (Table 3$)$. Emergence counts were not statistically significant between the three treatments at $P<0.05$. Stem counts were significantly lower $(P<0.05)$ for all the inoculated plots compared with the control.

Stolon and root diseases. Plants grown in plots treated with both seed tuber- and soilborne inoculum had significantly $(P<0.05)$ higher levels of root infection compared with either of them separately (Table 4). Similarly, treatments containing soilborne inoculum had significantly higher levels of root and stolon infection than the treatment where the inoculum source was tuber alone.

Stem canker and black scurf. Levels of stem canker and black scurf DI in field plots with a combination of infested soil and infected tubers were significantly higher $(P<0.05)$ than the treatments with soil or seed tuberborne inoculum alone (Table 4$)$. Stem canker DI was also significantly higher $(P<0.05)$ for plants grown with tuberborne inoculum than when infested soil was the only inoculum source. However, black scurf DI values were comparable in treatments with soilborne or seed tuberborne inoculum alone (Table 4).

Genotypic shift in the $R$. solani AG 3-PT population under field conditions. $R$. solani AG 3-PT isolates obtained from symptomatic tissues over the 2-year period at four different sampling time points over two growing seasons were genotyped using PCR-RFLP to quantify and infer the relative contribution of seed tuberborne and soilborne inocula to disease development on potato. In total, 151 isolates were isolated from symptomatic tissues. Seed tuberborne genotypes accounted for $60 \%$ of the recovered isolates while soilborne genotypes accounted for $36 \%$ of the recovered isolates, and the remaining $4 \%$ of the recovered isolates did not match either inoculum genotype and were isolated from plants growing in plots where both forms of inocula were present (Table 5). Isolates with genotypes identical to the inoculants were found only in plots where they were inoculated. Therefore, further work was carried out to elucidate whether the appearance of noninoculated genotypes was due to evolutionary forces such as sexual recombination and how the established experimental field population changed over two growing seasons.

In plots inoculated with both sources of inoculum, DI values of stolon or stem canker, root infection, and black scurf were significantly different from treatments inoculated with soilborne inoculum and seed tuberborne inoculum separately. However, disease occurrence could not be linked to a source of inoculum. Therefore, PCR-RFLP genotyping was carried out to correlate $R$. solani AG 3-PT isolates obtained to the genotype of origin. The PCR-RFLP DNA profiles indicated that tuberborne inoculum was more pronounced in causing black scurf and stem canker while soilborne inoculum caused more root infection but also contributed significantly to stolon cankers when results for both years were combined (Table 5; Fig. 1).

Table 6. Analyses of microsatellite genotypes of isolates of Rhizoctonia solani AG 3-PT recovered from potato in experimental plots

\begin{tabular}{|c|c|c|c|c|c|c|}
\hline Population ${ }^{v}$ & $N^{\mathrm{w}}$ & MLG $^{\mathbf{x}}$ & Released $(\%)^{\mathrm{y}}$ & Seed tuber-borne $(\%)$ & Soilborne (\%) & Nonreleased $(\%)^{z}$ \\
\hline 2013 Mid & 30 & 6 & $26(86)$ & 14 & 12 & $4(13)$ \\
\hline 2013 End & 32 & 6 & $28(87.5)$ & 17 & 11 & $4(12.5)$ \\
\hline 2014 Mid & 42 & 10 & $35(83)$ & 19 & 16 & $7(16)$ \\
\hline 2014 End & 53 & 11 & $44(80)$ & 20 & 24 & $9(16)$ \\
\hline Total & 157 & 33 & $133(84)$ & $70(53)$ & $63(47)$ & $24(15)$ \\
\hline
\end{tabular}

v Populations denoted by year and growth stage of sampling; Mid = tuber initiation and End = harvest.

${ }^{\mathrm{w}}$ Number of isolates with genotypes identical to a released inoculant's genotype.

${ }^{x}$ Multilocus genotypes (MLG) clone-corrected genotypes.

y All released isolates $(\%$ of $N$ ).

$\mathrm{z}$ All nonreleased isolates with genotypes different from the inoculants. 
Microsatellite analysis. In total, 157 R. solani AG 3-PT isolates were obtained from symptomatic tissue sampled over the two growing seasons (Table 6). Novel genotypes were identified at all sampling points, with 9 nonreleased genotypes out of 24 recovered at the end of 2014 growing season. Of the 24 nonreleased genotypes, 9 had new alleles at locus TC_AG3_0 and TC_AG3_19. Tuberborne inoculum contributed $53 \%$ of the recovered genotypes while soilborne contributed $47 \%$ of the released genotypes. A greater proportion of recovered isolates ( $84 \%$ ) had genotypes matching the released inoculants, indicating the importance of the asexual component of $R$. solani AG 3-PT in disease epidemics on potato.

Allele frequencies in field samples. Microsatellite analysis indicated that seven of the eight loci were polymorphic at all sampling time points, except locus TC_AG3_7, which had the same alleles for all isolates, and this was not included in subsequent analyses (Table 7). All alleles that were present in the soilborne and seed

Table 7. Frequencies of alleles observed at eight microsatellite loci in Rhizoctonia solani AG 3-PT isolates from four populations isolated from experimental plots at different sampling times ${ }^{\mathrm{y}}$

\begin{tabular}{lcccccc}
\hline Locus & $\begin{array}{c}\text { Allele sizes } \\
\text { (bp) }\end{array}$ & Expected $^{\mathbf{z}}$ & $\begin{array}{c}\mathbf{2 0 1 3} \\
\text { Mid }\end{array}$ & $\begin{array}{c}\mathbf{2 0 1 3} \\
\text { End }\end{array}$ & $\begin{array}{c}\mathbf{2 0 1 4} \\
\text { Mid }\end{array}$ & $\begin{array}{c}\mathbf{2 0 1 4} \\
\text { End }\end{array}$ \\
\hline TC_AG3_0 & 151 & 1.00 & 0.98 & 0.97 & 0.96 & 0.93 \\
& 160 & 0.00 & 0.02 & 0.03 & 0.04 & 0.07 \\
TC_AG3_1 & 152 & 0.72 & 0.76 & 0.74 & 0.72 & 0.57 \\
& 165 & 0.28 & 0.24 & 0.30 & 0.28 & 0.43 \\
TC_AG3_6 & 197 & 0.50 & 0.50 & 0.46 & 0.54 & 0.55 \\
& 203 & 0.50 & 0.50 & 0.54 & 0.46 & 0.45 \\
TC_AG3_7 & 244 & 1.00 & 1.00 & 1.00 & 1.00 & 1.00 \\
TC_AG3_10 & 245 & 0.88 & 0.76 & 0.69 & 0.70 & 0.84 \\
& 248 & 0.12 & 0.24 & 0.31 & 0.30 & 0.16 \\
TC_AG3_16 & 323 & 0.25 & 0.43 & 0.26 & 0.26 & 0.27 \\
& 327 & 0.25 & 0.07 & 0.24 & 0.24 & 0.24 \\
& 330 & 0.25 & 0.07 & 0.24 & 0.24 & 0.23 \\
TC_AG3_18 & 346 & 0.25 & 0.43 & 0.26 & 0.26 & 0.26 \\
& 321 & 0.25 & 0.43 & 0.25 & 0.26 & 0.29 \\
& 324 & 0.25 & 0.42 & 0.26 & 0.26 & 0.27 \\
TC_AG3_19 & 346 & 0.50 & 0.15 & 0.49 & 0.48 & 0.44 \\
& 320 & 0.25 & 0.07 & 0.25 & 0.24 & 0.22 \\
& 324 & 0.00 & 0.00 & 0.01 & 0.01 & 0.01 \\
& 343 & 0.43 & 0.26 & 0.26 & 0.26 & 0.30 \\
& 346 & 0.25 & 0.43 & 0.25 & 0.25 & 0.27 \\
& 356 & 0.25 & 0.07 & 0.23 & 0.24 & 0.20 \\
\hline
\end{tabular}

y Sampling points: $\mathrm{Mid}=$ midseason, sampled at tuber initiation, and End = end of growing season, sampled at tuber harvesting stage.

${ }^{\mathrm{z}}$ Expected allele frequencies based on alleles observed in inoculant isolates. tuberborne inoculants were observed in the $R$. solani AG 3-PT isolates obtained from experimental plots at each sampling time point (Table 8). Allele frequencies at all loci remained fairly constant, except for the frequency of the 321-bp allele at locus TC_AG 3_18, which decreased, whereas the frequency of 165 at locus TC_AG3_1 increased.

Population differentiation and divergence in field populations. A recovered genotype was considered a possible recombinant if it contained all of the alleles that were common to the released genotypes. Genotypic diversity seemed to increase slightly but not significantly over the successive sampling time points over the 2-year study, from 0.6 in 2013 to 0.72 in 2014 (Table 8). The expected heterozygosity (Nei's unbiased gene diversity) remained fairly constant over the sampling time points and growing years (from 0.24 to 0.27). Among the four sampling points, 2013 midseason had the lowest gene diversity (0.24), while the 2014 end of season had the highest (0.27). When the $R$. solani AG 3-PT population were divided by year, Nei's genetic diversity rose slightly from 0.26 in 2013 to 0.28 in 2014 (Table 6). The unbiased expected heterozygosity did not differ significantly in 2013 $\left(H_{\mathrm{E}}=0.40\right)$ as compared with $2014\left(H_{\mathrm{E}}=0.41\right)$. The observed heterozygosity remained fairly constant across the years, 0.6 in 2013 and 0.62 in 2014 (Table 8). Negative $F_{\text {IS }}$ values were observed for all the populations. Multilocus measures of association $\left(\mathrm{I}_{\mathrm{A}}\right.$ and $\left.\mathrm{rBarD}\right)$ were significant $(P<0.01)$ for all populations, providing strong evidence of rejection of the random mating hypothesis (Table 8). The value of $\mathrm{I}_{\mathrm{A}}$ ranged from 2.69 (2014 midseason) to 2.94 (2013 midseason) and the corresponding values of $\mathrm{rBarD}$ ranged from 0.54 (2014 end of season) to 0.72 (2013 midseason) (Table 8). However, there was a gradual decrease in multilocus measures of association as the seasons progressed.

Population differentiation was estimated using $F_{\mathrm{ST}}$. The $F_{\mathrm{ST}}$ values indicated little genetic differentiation among populations across the years. The pairwise $F_{\mathrm{ST}}$ values ranged from -0.008 to 0.054 , and only 2013 midseason values were significantly differentiated from 2014 end of season $(P<0.05)$. There was no differentiation between populations at other sampling time points, with the $F_{\mathrm{ST}}$ ranging from -0.008 to 0.054 .

\section{Discussion}

Rhizoctonia infection affects the quality and quantity of potato tubers (Banville 1989). Integrated management of diseases on potato caused by $R$. solani involves, among other strategies, reducing the pathogen population in primary sources of inoculum and preventing the genetic changes of the pathogen in the field. A better understanding of the contribution of different sources of inoculum to Rhizoctonia disease development on potato and the concomitant understanding of Rhizoctonia pathogen evolution would contribute to long-term effective disease management.

Several studies have been conducted to investigate the influence of inoculum source of $R$. solani on potato disease development (Atkinson

Table 8. Genetic diversity indices for Rhizoctonia solani AG 3-PT populations isolated from different sampling times calculated from microsatellite data

\begin{tabular}{|c|c|c|c|c|c|c|c|c|c|c|}
\hline Sampling times & $N^{\mathrm{q}}$ & $G^{r}$ & $\mathrm{Ne}^{\mathrm{s}}$ & $I_{A}{ }^{t}$ & rBarD $^{u}$ & Allelic richness $^{v}$ & $E_{5}{ }^{\mathrm{w}}$ & $F_{\text {IS }}{ }^{\mathbf{x}}$ & $H_{0}{ }^{y}$ & $H_{\mathrm{E}}^{\mathrm{z}}$ \\
\hline \multicolumn{11}{|l|}{ Between points } \\
\hline 2013 Mid & 30 & 0.60 & 0.24 & $2.94 *$ & $0.72 *$ & 2.00 & 0.54 & -0.2 & 0.6 & 0.39 \\
\hline 2013 End & 32 & 0.67 & 0.26 & $2.75^{*}$ & $0.58^{*}$ & 1.98 & 0.56 & -0.3 & 0.59 & 0.41 \\
\hline 2014 Mid & 42 & 0.70 & 0.26 & $2.69 *$ & $0.50^{*}$ & 2.0 & 0.53 & -0.2 & 0.62 & 0.41 \\
\hline 2014 End & 53 & 0.72 & 0.27 & $2.72^{*}$ & $0.54^{*}$ & 1.96 & 0.44 & -0.1 & 0.61 & 0.40 \\
\hline \multicolumn{11}{|l|}{ Between years } \\
\hline 2013 & 62 & 0.627 & 0.26 & $2.85^{*}$ & $0.67 *$ & 2.0 & 0.54 & -0.3 & 0.6 & 0.40 \\
\hline 2014 & 95 & 0.715 & 0.28 & $2.72 *$ & $0.55^{*}$ & 2.0 & 0.57 & -0.2 & 0.62 & 0.41 \\
\hline
\end{tabular}

q Number of isolates genotyped.

${ }^{r}$ Genotypic diversity, defined as the probability that two individuals taken at random have different genotypes (Nei 1987).

s Nei's unbiased gene diversity, based on 1,000 permutations computed in FSTAT, version 2.9.3.2 (Nei 1987).

t Standardized index of association; values that differ significantly from zero indicate departure from linkage equilibrium. Asterisks $(*)$ indicate significant at $P<0.01$.

u Standardized index of association (unbiased estimate of multilocus linkage disequilibrium). Asterisks $(*)$ indicate significant at $P<0.01$.

v Calculated according to El Mousadik and Petit (1996).

${ }^{\mathrm{w}}$ Index of evenness.

${ }^{x}$ Fixation index.

y Observed heterozygosity.

${ }^{\mathrm{z}}$ Expected heterozygosity. 
et al. 2010; Brierley et al. 2016; Carling et al. 1989; Tsror (Lahkim) and Peretz-Alon 2005). However, these studies differ as to which inoculum source is more important for causing Rhizoctonia disease epidemics on potato. In this study, both inoculum sources were important in causing black scurf on progeny tubers. Seed tuberborne inoculum was more prominent in causing stem canker whereas soilborne inoculum was associated more with root and stolon infection (Table 4; Fig. 1). Soilborne and seed tuberborne inoculum of $R$. solani AG 3-PT was demonstrated to have an additive effect in causing potato diseases. Treatments with a combination of soilborne and seed tuberborne inoculum had significantly higher stem canker and black scurf disease indices (Table 4). The observations from this study corroborated well with field studies conducted in The Netherlands (van Emden 1965) and Israel (Tsror (Lahkim) and Peretz-Alon 2005), among others, that demonstrated the additive effect of seed tuberborne and soilborne inoculum in causing diseases on potato.

From the PCR-RFLP genotyping results obtained in this study, both seed tuber- and soilborne inocula were etiologically important. Seed tuberborne inoculum resulted in slightly more infections on stems and progeny tubers (Fig. 1). van Emden (1965) surmised that seed tuberborne inoculum is nearest to the developing shoots and is of greater importance in causing stem canker than soilborne inoculum.

Soilborne inoculum also appeared to play a role in causing infection on roots and stolons and black scurf on progeny tubers. Tsror (Lahkim) and Peretz-Alon (2005) reported that soilborne inoculum increased the severity of black scurf while Brierley et al. (2016) proved that soilborne inoculum is an important source of inoculum in causing black scurf on potato. This indicates that, if pathogenfree seed tubers are sown in infested soil, the soil becomes the only source of inoculum. Frank and Leach (1980) postulated that, as stolons and roots grow through the soil and away from the seed piece inoculum, the inoculum in soil may become the primary source of infection of the stolon. The fact that both seed tuber- and soilborne inocula were consistently linked with high stem and black scurf disease indices demonstrates the importance of both inoculum sources on development of potato diseases in South Africa. This is in contrast to the findings of James and Mackenzie (1972), which demonstrated the importance of soilborne inoculum alone in potato disease development.

The observation of high genetic diversity among $R$. solani AG 3-PT isolates sampled from the same field in South Africa in a separate study (Muzhinji et al. 2016) might indicate evolution of $R$. solani AG 3-PT within the course of the growing season, perhaps due to gene flow, mutation, or recombination. In commercial potato fields, it is difficult to ascertain the identity of the founding population or when introductions had occurred; therefore, identification of evolutionary forces is done retrospectively. This study on the relative importance of soil- or seed tuberborne inoculum has provided a unique opportunity to understand how genetic diversity is shaped and maintained in fields with minimum gene flow using the mark-release-capture strategy.

Of interest in this study was the identification of nonreleased genotypes (Tables 5 and 6). The identification of nonreleased isolates leads us to speculate on the role of recombination between field inoculants. There were two lines of evidence to support the assumption. First, the experiment to evaluate the relative contribution of soil- or seed tuberborne inoculum source was conducted in fumigated soils using disease-free seed tubers, minimizing the possibility of any other sources of inoculum. Second, white-collar, which contains basidiospores involved in sexual recombination, was observed on the potato stem base during tuber initiation. Furthermore, the contribution of evolutionary forces such as mutation to the formation of new genotypes is not expected within the time scale of this experiment. The key to controlling Rhizoctonia diseases on potato lies in the use of Rhizoctonia spp.-free seed tubers because of their importance in disseminating the disease and adding to the pool of soilborne inoculum.

Analysis of allelic associations and genotypic diversity is routinely used to infer reproductive strategies of plant pathogens and, in most cases, an increase in genetic diversity is the hallmark of sexual recombination (Keller et al. 1997, 2010). Over the course of the experiment, Nei's unbiased genetic diversity remained fairly constant, as expected for clonal and asexually reproducing populations.
Tests for multilocus associations showed that all four populations were in gametic disequilibrium, as indicated by high $\mathrm{I}_{\mathrm{A}}$ values (2.69 to 2.90 ). This suggests high clonality and predominance of asexual reproduction. Furthermore, rBarD was similarly high ( 0.50 to $0 \cdot 72)$, providing further evidence of higher clonality (Table 8 ). The detection of many isolates ( $n=$ 133) with genotypes identical to the soilborne and tuberborne inoculants is strong evidence that asexual reproduction contributed significantly to the disease epidemics in the population genetic changes experiment.

Our results demonstrated a significant level of clonality for all of the populations, with little evidence of sexual recombination. This is supported by the high proportion of repeated genotypes, with the inoculant genotypes dominating the population sampled. The discovery of nonreleased genotypes and gradual increase in genotypic diversity might suggest that, when the conditions are conducive for the formation of basidiospores, recombination occurs in the field. This might increase the potential formation of novel genotypes through combinations of new alleles. These new novel genotypes might successfully overseason and serve as the founding population for the next Rhizoctonia disease cycle. This could lead to significant changes in the genetic structure of field populations from year to year and might have practical implications for $R$. solani AG 3-PT management, given the risk of genetic change demonstrated in this study. The use of pathogen-free tubers or the successful treatment of seed tubers with fungicides could minimize the introduction of different genotypes of $R$. solani into the same field. Control measures aimed at limiting the sexual phase of $R$. solani AG 3-PT would reduce the emergence of new genotypes in the field. Therefore, a seed health management approach combining clean seed and fungicide seed treatments might result in significant disease control in the absence of substantial gene flow inoculum of $R$. solani.

\section{Acknowledgments}

This work was supported by funding from Potatoes South Africa. We thank The Potato Pathology Group at the University of Pretoria for helping with field and greenhouse work. N. Muzhinji received a studentship from the National Research Foundation and University of Pretoria and also thanks the Tobacco Research Board in Zimbabwe. The National Research Foundation is acknowledged for supporting this study and purchasing the DNA sequencing instrument (grant UID: 78566) used at the University of Pretoria.

\section{Literature Cited}

Agapow, P. M., and Burt, A. 2001. Indices of multilocus linkage disequilibrium. Mol. Ecol. Notes 1:101-102.

Atkinson, D., Thornton, M. K., and Miller, J. S. 2010. Development of Rhizoctonia solani on stems, stolons and tubers of potatoes. Effects of inoculums source. Am. J. Potato Res. 87:374-381.

Balali, G. R., Neate, S. M., Kasalkher, A. M., Stodart, B. J., Melanson, D. J., and Scott, E. S. 2007. Intraspecific variation of $R$. solani AG 3 isolates recovered from potato fields in Central Iran and South Australia. Mycopathologia 163: 105-115.

Banville, G. J. 1989. Yield losses and damage to potato plants caused by Rhizoctonia solani Kuhn. Am. Potato J. 66:821-834.

Bardin, M., Decognet, V., and Nicot, P. C. 2014. Remarkable predominance of a small number of genotypes in greenhouse populations of Botrytis cinerea. Phytopathology 104:859-864.

Bartz, F. E., Cubeta, M. A., Toda, T., Naito, S., and Ivors, K. L. 2010. An in planta method for assessing the role of basidiospores in Rhizoctonia foliar disease of tomato. Plant Dis. 94:515-520.

Bennett, R. S., Milgroom, M. G., Sainudiin, R., Cunfer, B. M., and Bergstrom, G. C. 2007. Relative contribution of seed-transmitted inoculum to foliar populations of Phaeosphaeria nodorum. Phytopathology 97:584-591.

Brierley, J. L., Hilton, A. J., Wale, S. J., Woodhall, J. W., and Lees, A. K. 2016. The relative importance of seed- and soil-borne inoculum of Rhizoctonia solani AG-3 in causing black scurf on potato. Potato Res. 59:181-193.

Carling, D. E., Kuninaga, S., and Brainard, K. A. 2002. Hyphal anastomosis reactions, rDNA internal transcribed spacer sequences, and virulence levels among subsets of Rhizoctonia solani anastomosis group-2 (AG-2) and AGBI. Phytopathology 92:43-50.

Carling, D. E., Leiner, R. H., and Westphale, P. C. 1989. Symptoms, signs and yield reduction associated with Rhizoctonia disease of potato induced by tuber borne inoculum of Rhizoctonia solani AG 3. Am. Potato J. 66:693-701.

Ceresini, P. C., Shew, H. D., Vilgalys, R., Gale, L. R., and Cubeta, M. A. 2002 Genetic diversity of Rhizoctonia solani AG-3 from potato and tobacco in North Carolina. Mycologia 94:437-449.

Das, S., Shah, F. A., Butler, R. C., Falloon, R. E., Stewart, A., Raikar, S., and Pitman, A. R. 2014. Genetic variability and pathogenicity of Rhizoctonia solani associated with black scurf of potato in New Zealand. Plant Pathol. 63:651-666. 
El Mousadik, A., and Petit, R. J. 1996. High level of genetic differentiation for allelic richness among populations of the argan tree [Argania spinosa (L.) Skeels] endemic to Morocco. Theor. Appl. Genet. 92:832-839.

Excoffier, L., and Lischer, H. E. L. 2010. Arlequin suite ver 3.5: A new series of programs to perform population genetics analyses under Linux and Windows. Mol. Ecol. Resour. 10:564-567.

Ferrucho, R. L., Ceresini, P. C., Ramirez-Escobar, U. M., McDonald, B. A., Cubeta, M. A., and García-Domínguez, C. 2013. The population genetic structure of Rhizoctonia solani AG-3PT from potato in the Colombian Andes. Phytopathology 103:862-869.

Ferrucho, R. L., Zala, M., Zhang, Z., Cubeta, M. A., Garcia-Dominguez, C., and Ceresini, P. C. 2009. Highly polymorphic in silico-derived microsatellite loci in the potato-infecting fungal pathogen Rhizoctonia solani anastomosis group 3 from the Colombian Andes. Mol. Ecol. Resour. 9:1013-1016.

Fiers, M., Chatot, C., Edel-Hermann, V., Hingrat, L. Y., Konate, A. Y., Gautheron, N., Guillery, E., Alabouvette, C., and Steinberg, C. 2011. Genetic diversity of Rhizoctonia solani associated with potato tubers in France. Mycologia 103: 1230-1244.

Frank, J. A., and Leach, S. S. 1980. Comparison of tuber-borne and soil-borne inoculum in the Rhizoctonia disease of potato. Phytopathology 70:51-53.

Glaubitz, J. C. 2004. Convert: A user-friendly program to reformat diploid genotypic data for commonly used population genetic software packages. Mol. Ecol. Notes 4:309-310.

Goudet, J. 1995. FSTAT (Version 1.2): A computer program to calculate F-statistics. J. Hered. 86:485-486.

James, W. C., and McKenzie, A. R. 1972. The effect of tuber-borne sclerotia of Rhizoctonia solani Kuhn on the potato crop. Am. Potato J. 49:296-301.

Jeger, M. J., Hide, G. A., van den Boogert, P. H. J. F., Termorshuizen, A. J., and van Barrlen, P. 1996. Pathology and control of soil-borne pathogens of potato. Potato Res. 39:437-469.

Keller, M. D., Waxman, K. D., Bergstrom, G. C., and Schmale, D. G., III. 2010. Local distance of wheat spike infection by released clones of Gibberella zeae disseminated from infested corn residue. Plant Dis. 94:1151-1155.

Keller, S. M., McDermott, J. M., Pettway, R. E., Wolfe, M. S., and McDonald, B. A. 1997. Gene flow and sexual reproduction in the wheat glume blotch pathogen Phaeosphaeria nodorum, (anamorph Stagonospora nodorum). Phytopathology 87:353-358.

McDonald, B. A., and Linde, C. 2002. The population genetics of plant pathogens and breeding strategies for durable resistance. Euphytica 124:163-180.

Meirmans, P. G., and van Tienderen, P. H. 2004. GenoType and GenoDive: Two programs for the analysis of genetic diversity of asexual organisms. Mol. Ecol. Notes 4:792-794.

Muzhinji, N., Truter, M., Woodhall, J. W., and van der Waals, J. E. 2015. Anastomosis groups and pathogenicity of Rhizoctonia solani and binucleate Rhizoctonia from potatoes in South Africa. Plant Dis. 99:1790-1802.
Muzhinji, N., Truter, M., Woodhall, J. W., and van der Waals, J. E. 2016. Population genetic structure of Rhizoctonia solani AG 3-PT associated with potato diseases in South Africa. Fungal Biol. 120:701-710.

Nei, M. 1987. Molecular Evolutionary Genetics. Columbia University Press, New York

Ogoshi, A. 1975. Grouping of Rhizoctonia solani Kühn and their perfect stages. Rev. Plant Prot. Res. 8:93-103.

Ogoshi, A. 1987. Ecology and pathogenicity of anastomosis and intraspecific groups of Rhizoctonia solani Kühn. Annu. Rev. Phytopathol. 25:125-143.

Peakall, R., and Smouse, P. E. 2006. GENALEX 6: Genetic analysis in Excel Population genetic software for teaching and research. Mol. Ecol. Notes 6 : 288-295.

Shah, D. A., Bergstrom, G. C., and Ueng, P. P. 1995. Initiation of Septoria nodorum blotch epidemics in winter wheat by seed-borne Stagonospora nodorum. Phytopathology 85:452-457.

Shew, H. D., and Melton, T. A. 1995. Target spot of tobacco. Plant Dis. 79:5-11.

Simons, S. A., and Gilligan, C. A. 1997. Factors affecting the temporary progress of stem canker ( $R$. solani) on potatoes (Solanum tuberosum). Plant Pathol. 46: 642-650.

Sneh, B., Jabaji-Hare, S., Neate, S., and Dijst, G., eds. 1996. Rhizoctonia Species: Taxonomy, Molecular Biology, Ecology, Pathology and Disease Control Kluwer Academic Publishers, Dordrecht, The Netherlands.

Sneh, B., Katan, J., Henis, Y., and Wahl, I. 1966. Methods for evaluating inoculum density of Rhizoctonia in naturally infected soil. Phytopathology 56:74-78.

Sommerhalder, R. J., McDonald, B. A., Mascher, F., and Zhan, J. 2010. Sexual recombinants make a significant contribution to epidemics caused by the wheat pathogen Phaeosphaeria nodorum. Phytopathology 100:855-862.

Tsror, L. 2010. Biology, Epidemiology and Management of Rhizoctonia solani on potato. J. Phytopathol. 158:649-658.

Tsror (Lahkim), L., and Peretz-Alon, I. 2005. The influence of the inoculum source of Rhizoctonia solani on development of black scurf on potato. J. Phytopathol. 153:240-244.

van Emden, J. H. 1965. Rhizoctonia solani; results of experiments. Eur. Potato J. $8: 188-189$.

Woodhall, J. W., Lees, A. K., Edwards, S. G., and Jenkinson, P. 2007 Characterization of Rhizoctonia solani from potato in Great Britain. Plant Pathol. 56:286-295.

Woodhall, J. W., Lees, A. K., Edwards, S. G., and Jenkinson, P. 2008. Infection of potato by Rhizoctonia solani: Effect of anastomosis group. Plant Pathol. 57:897-905.

Zhan, J., and McDonald, B. A. 2013. Field-based experimental evolution of three cereal pathogens using a mark-release-recapture strategy. Plant Pathol. 62: 106-114.

Zhan, J., Mundt, C. C., and McDonald, B. A. 1998. Measuring immigration and sexual reproduction in field populations of Mycosphaerella graminicola. Phytopathology 88:1330-1337. 